\title{
Tourism Management in Tahura Sultan Adam (Case Study in Mandiangin Timur Village and Mandiangin Barat)
}

\author{
Juhrani* , Andi Tenri Sompa, Taufik Hidayat \\ Master Program of Government Science, Lambung Mangkurat University, Banjarmasin, Indonesia
}

\author{
DOI: $\underline{10.36348 / \text { sijlcj.2020.v03i06.005 }}$ \\ | Received: 29.05.2020 | Accepted: 06.06.2020 | Published: 12.06.2020 \\ *Corresponding author: Juhrani
}

\section{Abstract}

Sultan Adam Tahura is the largest Tahura area in Indonesia. A Tahura which has the widest area is both a pride and a challenge in maintaining and managing this area so that it can benefit the community, both ecologically, economically, and socially. This study aims to describe how the management of Sultan Adam's Tahura natural tourism in several ways perspective development. A qualitative approach is used in research. To provide in-depth descriptions, descriptive methods are implemented. Data collection stages through three stages. Analysis model of Miles and Huberman chose for present narrative text in research. The results of the study describe that the Community Empowerment Program that has been implemented following the principle of community empowerment in the management of the Sultan Adam Tahura natural tourism in Belangian Village, Aranio Subdistrict, Banjar Regency is as follows: 1) Program for the Use of Village Fund Allocation, 2) the Riam Kanan Watershed Rehabilitation Program, 3) Social Forestry Program in the form of Forestry Partners, and 4) Tourism Village Development Program. The fourth economic impact of the Community Empowerment Program implemented in Belangian Village, the District as a whole can be concluded that it has been able to improve the welfare of Belangian Village residents.

Keywords: Tahura, village development, and welfare.

Copyright @ 2020: This is an open-access article distributed under the terms of the Creative Commons Attribution license which permits unrestricted use, distribution, and reproduction in any medium for non-commercial use (NonCommercial, or CC-BY-NC) provided the original author and source are credited.

\section{Preliminary}

Sultan Adam Tahura which was designated as a conservation area based on Presidential Decree No. 52 of 1989 with an area of $112,000 \mathrm{Ha}$, was very fulfilling the criteria of various aspects to be designated as a grand forest park (Tahura) because it has the characteristics of aspects of the ecosystem, has extraordinary natural beauty and diverse, and very possible for a place to grow and develop animals and plants in it [1]. Based on the provisions of Presidential Decree No. 52 of 1989, the purpose of establishing Sultan Adam Forest Park is; for the preservation and collection of flora and fauna germplasm, facilities for tropical rain forest and fauna vegetation research, natural tourism facilities and fostering a love for Indonesia, education/training and extension services for the community, maintain the natural beauty and to create a fresh climate, and improve hydro-orological functions in the Riam Kanan watershed (DAS) which have a major influence on agricultural areas. In further developments, the area of Tahura Sultan Adam increased to 113,617 hectares by Minister of Forestry Decree Number 144 / Kpts-II / 2003 April 22, 2003, and Minister of Forestry Decree Number 164 / MenhutII / 2010 dated March 31, 2010.

Sultan Adam Forest Park Area (Tahura) includes several areas, namely Riam Kanan Protected Forest, Kinain Buak Protected Forest, Pelaihari Martapura Wildlife Reserve, Riam Kanan River Basin and Educational Forest of Lambung Mangkurat University. Administratively, the Tahura Sultan Adam area is located in two regions, namely Banjar Regency and Tanah Laut Regency. Sultan Adam Tahura area with an area of 113,617 hectares is the largest Tahura area in Indonesia.

The management of the Tahura Sultan Adam area with an area of 113,617 hectares which spans two administrative regions, namely Banjar Regency and Tanah Laut Regency, by the applicable laws and regulations, the management of the area is under the authority of the South Kalimantan Provincial Government. Technically the management of Tahura is carried out by the Technical Implementation Unit (UPT) of Tahura Sultan Adam which is under the Forestry Service of South Kalimantan Province based 
on South Kalimantan Province Regional Regulation No. 7 of 2010 concerning Management of Sultan Adam Forest Park.

In the Sultan Adam Tahura area, there are many villages and settlements, villages and settlements in the Sultan Adam Tahura area were formed before the adoption of the Sultan Adam Tahura as a conservation area or formed after the issuance of Presidential Decree No. 52 of 1989 dated October 18, 1989.

The existence of villages in the Tahura Sultan Adam area has the potential for the progress or development of the Tahura Sultan Adam, but on the other hand, it can be a challenge in the construction of the Tahura Sultan Adam. As a Tahura conservation area it functions to preserve and collect flora and fauna germplasm, facilities for research into the tropical rainforest and fauna vegetation, natural tourism facilities and the promotion of Indonesian love, educational / training advice and counseling for the community, maintaining the natural beauty and for creating a favorable climate fresh, and improve hydroorological functions in the Riam Kanan watershed.

Of the many villages in the Sultan Adam Tahura area, there is Belangian Village located in the upper Riam Kanan watershed (DAS) which is included in the administrative area of Aranio Subdistrict, Banjar Regency. As one of the villages in the Sultan Adam Tahura area, Belangian Village existed before the formation of the Sultan Adam Tahura based on Presidential Decree No. 52 of 1989. Belangian Village is a very important village because it has a hydroorological function for the Riam Kanan watershed. Belangian Village's position is very important because it is located at the far end of the Riam Kanan watershed, which is mostly mountainous, hilly, plain, and lake.

Besides having a hydro-orological function for the Riam Kanan watershed area, Belangian Village has a very extraordinary natural tourism potential because it is located in the Meratus Geopark area which has many natural attractions in the form of beautiful mountain views, cascades, rivers with rocks beautiful and unique, tropical rain forests, primary ulin forests, nature lover tracking roads, Kahung Valley waterfalls and others.

Natural tourism objects in this conservation forest area have become new natural tourism destinations in South Kalimantan and have already been visited by adventurers, nature lovers, students, local tourists and national tourists on weekends, compared to other natural attractions such as the Flower Island and Mandiangin the number of tourist visits is still very low. To increase the number of tourist visits to Belangian Village requires better management from stakeholders. With the launch of Belangian Village as a tourist village with two other villages in South Kalimantan, namely Tiwingan Lama Village and Haratai Village in Loksado
District, it is expected that the number of tourist visits in the year will increase.

In the management of Tahura Sultan Adam's natural tourism in the Belangian Village area, as well as the management of natural tourism in other areas should be able to provide greater opportunities for the local community to be more actively involved so that the welfare of the local community increases. One activity that can be carried out to improve community welfare is through community empowerment programs. Community Empowerment is an effective activity in the framework of empowering and empowering the community. Community empowerment activities can be done anytime, anywhere, and by anyone. Basically community empowerment activities are aimed at the poor, so that they are independent and able to help themselves [2].

In its realization, most community empowerment focuses on economic empowerment in the context of poverty alleviation and poverty reduction. Community empowerment is always done in the form of developing productive activities to increase income (income generating) [3]. The need for community empowerment in natural tourism management because there are still some Belangian Village residents whose welfare level is still low and needs to be improved. Based on Belangian Village Government population data in 2019, in Belangian Village there are still 30 residents as recipients of the Hope Family Program $(\mathrm{PKH}), 16$ residents as recipients of welfare rice assistance (Rastra), and 50 residents as recipients of the National Health Insurance (JKN).

To ensure community empowerment in the management of natural tourism in Belangian Village, it needs to be done with the right approach. So that community empowerment efforts by stakeholders can run well and smoothly so that the goal of community empowerment is to improve the welfare of the local community can be achieved. Furthermore, to ensure the implementation of community empowerment in the management of natural tourism in Belagian Village, it is necessary to support an appropriate program of activities and meet the principles of community empowerment as stated by Soedijanto [4] in Mardikanto, namely volunteerism, autonomy, self-help, participatory, egalitarian, democracy, togetherness, accountability, and decentralization.

Community empowerment can be considered successful if the programs and activities planned and implemented can bring economic impacts to the people involved. This means that programs or activities carried out in the empowerment process can improve the welfare of the local community involved. In this study, an empowerment approach that will be identified by the program implemented and the implementation of the community empowerment program will have an impact 
on economic improvement or can improve their welfare.

\section{RESEARCH METHODS}

This research examines Community Empowerment in the Management of Nature Tourism Tahura Sultan Adam with locus in Belangian Tourism Village, Karang Intan District, Banjar Regency, conceptually, the approach in this study refers to the descriptive research principles which are a research model oriented to describe there is a relationship between variables or factors that influence the emergence of a social phenomenon which is the object of study $[5,6]$.

Based on the perspective of the research objectives, the choice of design or research design which is then chosen as the case study research design, namely a systematic investigation of an event (event) or a specific phenomenon (Sarman, Thesis Guidelines for Research Procedures and Writing a Thesis, 2004) [7]. Case studies are not a methodological choice, but rather an object of choice to study. The case study is known as a study that is comprehensive, intense, detailed, and indepth and directed as an effort to examine problems or phenomena that are contemporary to a person or a social unit for a certain period [6].

To obtain accurate data that is relevant to the research topic, the following data collection techniques are used. First, observation is carried out through direct observation in the field of the real conditions that occur. Second, interviews, namely through direct interviews with predetermined respondents and thirdly documentation. The unit of analysis in this study is the Belangian Village Supporting Forestry Instructor, Belangian Village Head (Pambakal), Belangian Village Officials, Chairperson of the Forest Farmer Group $(\mathrm{KTH})$, and Chairperson of the Tourism Awareness Group (Pokdarwis), Head of Youth Organization and Head of Belangian Environment who is involved directly and indirectly in the management of nature tourism in Belangian Village, Aranio District, Banjar Regency.

The instruments used in this research are; (1) interview guidelines made for direct interviews with parties who know and are related to Community Empowerment in the management of Sultan Adam's Tahura natural tourism located in Belangian Tourism Village and (2) observation guidelines for observing matters relating to natural tourism management and Tourism Village management, infrastructure, community or community behavior. Besides that, to support research it is also necessary to analyze the means of documentation that can support research (Sarman, Introduction to the Social Research Methodology, 2004) [7].
In this study triangulation data analysis techniques were used which are based on three data sources namely observation, interviewees, and documents. The triangulation method is generally understood as a process that uses multi-perception to clarify the meaning of information obtained in the field, make verification or repeat observations, and finally interpret them [8]. The data that has been obtained is then analyzed using qualitative descriptive analysis. Qualitative descriptive analysis is an analysis realized by describing the reality or circumstances or an object in the form of sentence descriptions based on the statements of the parties directly related to the research [9].

\section{RESULTS AND DISCUSSION}

Belangian Village is the last village in the upper reaches of the Riam Kanan watershed, which is included in the area administration ratio District. As a village that is included in a conservation area, its development must pay attention to various aspects, such as environmental, socio-cultural, economic, and legal aspects. Unlike the development of other villages, the development of Belangian Village which is included in the conservation area is rather complicated, because every program of activities carried out and in contact with environmental conservation must be carried out carefully so as not to have legal consequences in its implementation.

As a village which is a remote village because it is far from the Aranio Subdistrict City Center and to get to Belangian Village can only be accessed by using transportation klotok or ship with a long journey of almost two hours. Although it is classified as a remote village because it is located at the far end of the Riam Kanan watershed, Belangian Village cannot be classified as a backward or poor village. When viewed from aspects of orderly government administration, awareness of environmental sustainability, deep observance religious, health status, and education level, then Belangian Village can be classified as a developed village.

Moreover, with the launching of Belangian Village as a Tourism Village by the Forest Service of South Kalimantan Province because it has a unique, beautiful and attractive natural tourism potential, according to the statements of some local community leaders, in the future Belangian Village will be more advanced and will become a tourist destination new seed in South Kalimantan.

As we know, the purpose of the development program in the village, both carried out by the central government, provincial government, district/city government and village government itself is basically to improve the welfare of citizens. Therefore it is expected that various programs and activities included in the development of the Sultan Adam Tahura natural 
tourism especially in the Belangian Tourism Village should better optimize the empowerment of the local community. To find out more about various programs and activities in Belangian Tourism Village that pay attention to aspects of community empowerment can be described as follows:

\section{Community Empowerment in the Village Fund Allocation Program}

Based on Belangian Village APBDes in 2019, the total income of Belangian Village is Rp.1,105,706,885, - with village expenditures of Rp.1,033,553,865, - Silpa in 2018 of Rp.14,773,392 and additional capital allocated to BUMdes of Rp. $.86,926,412$. As a detailed description of the use of village funds for the Belangian Tourism Village can be seen in the 2019 APBDes Infographics as shown below:

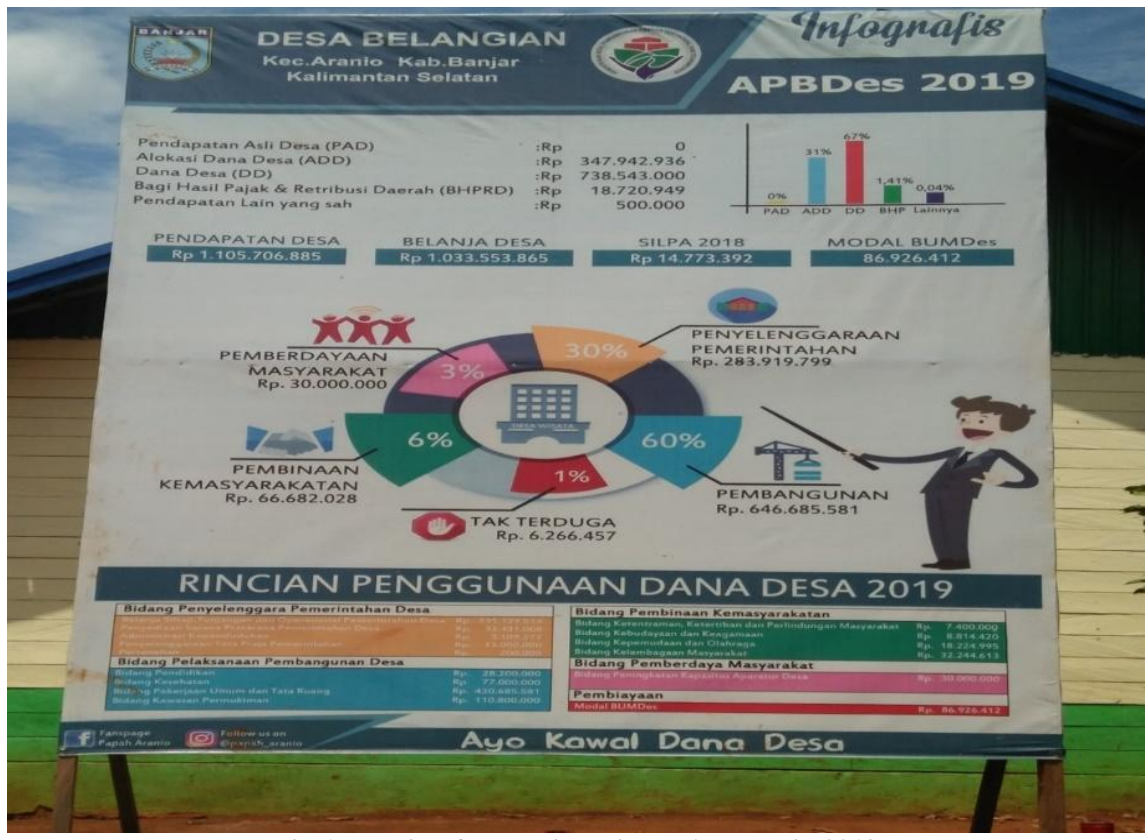

Fig-1: Details of Belangian Village APBDes in 2019

Based on the 2019 APBDes above, for the program in the field of Community Empowerment in the Capacity Building activities of the Village Apparatus allocated Rp. 30,000,000. - The allocation of funds for community empowerment for comparative study purposes and training of village officials to increase the capacity of the village apparatus, both which is carried out within the region and outside the region, and the results of the capacity building will be transmitted to community members and groups in Belangian Village.

In the implementation of village physical development sourced from village funds amounting to Rp.646,685,581.00, the allocation is used to build various village facilities and infrastructures such as repairing environmental roads, village roads, garbage bins, and other infrastructure facilities under Village Government policies. Since 2017 all activities related to development must involve all members of the community following their abilities as a form of community empowerment around the area with the right approach to improve their welfare. According to Mardikanto [10] Empowerment approach can also be formulated by referring to the philosophical principles and principles of empowerment, namely:
1. Participatory Approach, in the sense that in carrying out empowerment always put community as the focal point for implementing empowerment.

2. Welfare Empowerment, in the sense that any activities carried out, regardless of the resources and technology used, and anyone involved in community empowerment must provide benefits to improve the quality of life or welfare of the beneficiary community.

3. Sustainable Development Approach, in the sense that every activity of community empowerment must be guaranteed continuity therefore empowerment must not create dependency which means the community must be able to be independent.

The community empowerment approach in the use of village fund allocations leads to the welfare approach because the use of village fund allocations is entirely directed at providing benefits to improving the quality of life or to improving the welfare of all Belangian Village residents [10]. For example, there is a concept of community empowerment with a welfare approach, namely in the activities of the field of village development sourced from village funds including the 
construction of village roads, multipurpose buildings, rehabilitation of the Health Post and the construction of a toilet/bathroom where all workers in carrying out these activities come from the community Belangian Village itself is following its expertise/skills. Likewise with the procurement of construction materials such as mountain rocks, coral, sand,

Besides that, also following applicable regulations, the Village Government is allowed to build and develop Village-Owned Enterprises (BUMDes) with certain businesses that can support the implementation of the village development process to obtain profits which will later be used as working capital for BUMdes. Beldes Village BUMdes was established in 2017 under the name BUMdes Karya Bersama. One of the efforts carried out by BUMdes Karya Bersama is to develop seedlings of forestry plants and fruit trees sold to mining companies that carry out rehabilitation of critical land in the Riam Kanan Sub-watershed or to communities or other parties that need them.

The nursery owned by BUMDes, all of its workforce are young people and residents of Belangian Village itself. With the existence of BUMdes activities in the nursery of forestry plant seeds and fruit trees, these directly become a source of income for some community members. The types of plant seedlings that are currently being developed by BUMdes Karya
Bersama to meet the demand for seedlings for the rehabilitation of the Riam Kanan watershed in some mining companies are candlenut, jengkol and other fruit plants. The nurseries developed by BUMDes will be sold to coal mining companies for Rp.2,000 per tree.

Based on data from the Tahura Sultan Adam UPT to date six coal mining companies are undertaking the rehabilitation of the Riam Kanan watershed. Rehabilitation of critical land is instead of forest land that has been borrowed to use for coal mining needs in several districts in South Kalimantan. The mining companies that have collaborated with BUMdes Karya Bersama in the procurement of plant seeds for the rehabilitation of the Riam Kanan Sub-watershed are PT. Adaro, PT. Arutmin Indonesia, PT. Prolindo Citra Nusantara, PT. Tanah Bumbu Resource, PT. Angsana Jaya Energi and PT. Borneo Indobara.

\section{Community Empowerment in the Riam Kanan River Basin Rehabilitation Program}

To carry out rehabilitation of critical land in the upper Riam Kanan watershed, several mining companies operating in South Kalimantan are currently carrying out land rehabilitation activities in the Tahura Sultan Adam conservation area located in Belangian Village, Aranio District, Banjar Regency. The coal mining companies that currently carry out rehabilitation activities in the Riam Kanan watershed, which fall into the Belangian Village area, are as follows:

\begin{tabular}{|l|l|l|l|}
\hline No. & $\begin{array}{l}\text { Company name } \\
\text { IPPKH holder }\end{array}$ & $\begin{array}{l}\text { Land area } \\
\text { (Ha) }\end{array}$ & Information \\
\hline 1 & PT. Adaro Indonesia & 862 & Realization of 298 Ha \\
\hline 2 & PT. Arutmin Indonesia & 302 & Technical Design Process \\
\hline 3 & PT. Prolindo Cipta Nusantara (PCN) & 326 & Realization of 326 Ha \\
\hline 4 & PT. Tanah Bumbu Resources (TBR) & 326 & Realization of 25 Ha \\
\hline 5 & PT. Borneo Indobara (BIB) & 300 & There are no activities yet \\
\hline 6 & PT. Angsana Jaya Energi (AJE) & 127 & Realization of 25 Ha \\
\hline \multicolumn{2}{|l|}{ amount } & 2,243 & 674 Ha (Realized) \\
\hline
\end{tabular}

Source: UPT Sultan Adam Tahura in 2019

The planting locations for the rehabilitation of the Riam Kanan Sub-watershed, located in Belangian Village, are scattered in several places, some of the rehabilitation lands are on the left and right of the Belangian Village natural tourism trekking pathway to the Kahung Valley waterfall. Rehabilitation of critical land by six mining companies starting from the planning, planting, maintenance, and handover stages always involves the Belangian Village residents as a form of community empowerment.

In the process of planning the community around the area is allowed to choose the type of seeds or types of plants planted in the location plan [11]. The type of seedlings chosen are the types of forest plants or fruit plants that grow rapidly, have large trees, and produce fruit such as candlenut, jengkol, cashew, and others. After determining the type of plants chosen by the community members, the process of planting labor will be used by residents with a daily / piece-rate system. The length of time for maintenance following the provisions is for three years if within three years it turns out that in the location of the rehabilitation land the trees planted are still small or in the field is still a lot of weeds, the South Kalimantan Provincial Forestry Service has the right to refuse land surrender and as a result, the IPPKH company must carry out maintenance to the point where it is deemed to be eligible to be handed over. At this maintenance stage, the IPPKH company is also required to employ residents, the land that has been handled for three times must be protected from the danger of fire or destruction of livestock, thus for three years of land maintenance, there is the concept of community empowerment in the Riam Kanan watershed rehabilitation program. 
Within three years after planting, if the trees planted are already large enough and the land has been cleared of weeds, then the land will be handed over to the Forest Service of South Kalimantan Province, then the rehabilitated land will be handed over to the Forest Farmers Group (KTH) ) that are around the area, most KTH members are usually community members who have traditionally managed the land to cultivate rice fields or grow beans and chilies. After receiving the rehabilitation land, then KTH members have the right to manage and maintain them until they produce or produce fruit. The results of these plants such as candlenut, cashew,

The program of rehabilitation of critical land in the Riam Kanan watershed by six coal mining companies out of a total obligation to carry out an area of 2,243 hectares, to date only 674 hectares have been realized, all of which have not yet been handed over between coal mining companies and the Kalimantan Provincial Forestry Service South because it has not met the minimum maintenance period of 3 (three) years. For the rest of the obligation to rehabilitate 1,568 $\mathrm{Ha}$ of land continues to be implemented by utilizing the community around the Belangian Village.

The existence of a program of rehabilitation of degraded land in the Riam Kanan watershed is based on the explanation of several community leaders having a positive impact because through the program the community earns additional income in the form of wages and if the crop is turned over, then when it produces fruit it can also be sold to earn additional income. In the medium-term natural tourism management planning concept, in the four tracking lanes starting from Selter 1 (suspension bridge) to the Kahung Valley waterfall, honey bee cultivation and tourist stalls will also be built. The existence of honey bee cultivation and tourist stalls in the three shelters (resting place) is certainly increasing the income of people around the area.

\section{Empowerment Community through the Social Forestry Program}

Based on the provisions of the Regulation of the Minister of Environment and Forestry of the Republic of Indonesia Number P.83 / MENLHK / SETJEN / KUM.1 / 10/2016 concerning Social Forestry, what is meant by Social Forestry is "Sustainable forest management system implemented in the State forest area or private forest / customary forest implemented by the local community or customary law community as the main actor to improve welfare, environmental balance, and social-cultural dynamics in the form of village forests, Community Forests, Community Plantation Forests, Community Forests, Customary Forests, and Forestry Partnerships "
The background to the issuance of the Social Forestry policy is to reduce poverty, unemployment, and inequality in the management/utilization of forest areas through efforts to provide legal access to the community. Social Forestry under applicable regulations can be in the form of Village Forest Management, Community Forest Business Permit Management, Community Plantation Forest Management, and Forestry Partnership Management or recognition and protection of indigenous and tribal peoples whose purpose is for the welfare of the community around the area and the preservation of forest resources.

In the management of Social Forestry under the provisions of article 3 of the Regulation of the Minister of Environment and Forestry Number P.83 / MENLHK / SETJEN/KUM.1/10/2016, the principle that must be considered by stakeholders or members of the community around the forest area is the principle of justice, sustainability, legal certainty, participation and responsibility [12]. The purpose of the issuance of the Social Forestry regulation policy is to resolve tenurial issues (forest tenure/management rights) and justice for local communities and indigenous forest peoples who are in/around the forest area to improve community welfare and preservation of forest functions.

1. Village Forest (HD) is a state forest managed by the village and utilized for the benefit of the village. Village Forests are usually located in protected forest areas.

2. Community Forest $(\mathrm{HKm})$ is a state forest whose primary use is intended to empower communities, forests socially located in protected forests and industrial plantations (HTI).

3. Community Forest Plantation (HTR) is a plantation forest in a production forest (HTI) developed by a group of people to improve the potential and quality of production forests by applying silviculture in the context of guaranteeing forest resources.

4. Forestry Partnership is cooperation between the local community and the forest manager, the holder of a forest utilization/forest service business permit, a lease-to-use forest area permit, or the holder of a forest product primary industry permit, a forestry partnership for example forestry activities in a Tahura conservation area.

5. The customary forest is a forest within the territory of a customary law community, usually within a protected forest or conservation forest.

Under the provisions of Presidential Decree No. 52 of 1989 concerning the Development of the Right Riam Forest Group as Sultan Adam Forest Park, the purpose of the development of Sultan Adam Forest Park is to preserve and collect flora and fauna germplasm, a research facility for tropical rain forest vegetation types and types fauna of Borneo, a means of nature tourism and fostering the love of nature in 
Indonesia, maintaining the natural beauty and creating a fresh microclimate, and improving the function of hydro-orological the Riam Kanan watershed (DAS) which affects the quality of life of the people of South Kalimantan in general.

To carry out the development objectives of Tahura Sultan Adam, especially those related to the development of natural tourism facilities and the promotion of Indonesia's natural love, maintaining the natural beauty and creating a fresh microclimate, as well as to improve the hydro-orological functions of the Riam Kanan watershed (DAS) in Belangian Village area has been prepared by the location of Social Forestry in the form of a Forestry Partnership between the Forest Service of the Province of South Kalimantan (UPT Tahura Sultan Adam) with the community members around the area that traditionally they have managed the land to plant beans, cayenne pepper, bananas and plantations rubber and as cattle and buffalo fodder land.

The implementation of Social Forestry under the Forestry Partnership pattern has been implemented since the issuance of the Minister of Forestry Regulation of the Republic of Indonesia Number: P.39 / Menhut-II / 2013 concerning Empowerment of Local Communities through Forestry Partnerships. To implement the concept of Social Forestry in conservation areas using the Forestry Partnership model in Belangian Tourism Village, the Forest Service of South Kalimantan Province has proposed a 340-hectare land to the Minister of Environment and Forestry to be made a Forestry Partnership under the Conservation Partnership pattern. The location of the conservation partnership that will be built is located on the left and right of the tracking path to the Kahung Valley waterfall which starts from the nursery owned by BUMDes Karya Bersama to shelter 1 (Suspension Bridge) towards the natural tourism of the Kahung Valley waterfall. The Provincial Government of South Kalimantan, through the UPT Tahura Sultan Adam, carried out community empowerment. Communities around the area are no longer afraid and are anxious to carry out activities on conservation land that have been made into forestry partnerships.

Some activities carried out by the community on forestry partnership land in agriculture include planting mountain rice, peanuts, cayenne pepper, and banana. As for the plantation and animal husbandry sectors, some have planted rubber mixed with buffalo or cow raising. In connection with having declared Belangian Village as a tourist village by the Forest Service of South Kalimantan Province, the community members with the assistance of the Forestry Instructor at the forestry partnership location also developed honey bee cultivation.

\section{Community Empowerment through the Tourism Village Development Program}

In building a tourist village not only with a beautiful natural landscape but some important things must also be considered in the development of a tourist village [13, 14]. Beautiful natural, cultural, and potential creativity is a capital that must be maintained and considered in the development of a tourist village [15]. Belangian Village, Aranio Subdistrict is one of the villages declared by the Forest Service of South Kalimantan Province as a Tourism Village. As a Tourism Village, Belangian Village fulfills the requirements to be developed because it has the object of very interesting natural attractions such as the Kahung Valley waterfalls, tropical rain forests, charming natural mountain views, the river flows with beautiful giant rocks, and the object other interesting natural attractions.

The social culture of Belangian Village is a very religious community (Muhammadiyah), has a high tolerance, and is very open to change. The creative potential of youth and other members of the community is naturally very good and only a little need to be given guidance and training. The Belangian Village Government, supported by all its citizens, is very ready to receive more tourist visits. With the full support of the South Kalimantan Provincial Forestry Office and the Sultan Adam UPT Tahura as conservationists, the South Kalimantan Provincial Tourism Office and the Banjar District Tourism Office, this new tourism destination is believed to continue to develop faster.

The Belangian Village Government with the support of the South Kalimantan Provincial Forestry Service in the last two years has been constructing supporting facilities and infrastructure such as the construction of village/settlement roads, farming roads, tracking paths to the Kahung Valley waterfall, permanent port / klotok boat, public toilets, clean water installations, sports fields, repair of health facilities, multipurpose buildings, and others.

In supporting tourism activities, the Belangian Village Head has decided Decree Number: 02 / SK / I / 2016 dated January 15, 2015, concerning the Determination of the Tourism Awareness Group (Pokdarwis) Belangian Village Aranio Subdistrict Banjar Regency 2016. The Management Structure of the Belangian Pokdarwis Village Guidance (Tourism Office), Advisory (Belial Shop), Chair (Hasriani), assisted by the Secretary, Treasurer, Security and Order Section, Cleanliness Section, Tourism Attraction Section, Public Relations and HR Development Section, Business Development Section, and Members. In the management of Belangian Village tourism objects, the Village Government (Pembakal) has stipulated Belangian Village Regulation Number 1 of 2019 and Belangian Village Pambakal Decree Number: 01 / BLG / 2018 concerning Provisions for Kahung Valley 
Tourism Entrance. Based on the Village Regulation and the Decree of the Belangian Pembakal, the entrance fee for natural tourism objects is Rp. 2.000, - / person, tourist taxi Rp. 25,000, - / person (one pull up to the shelter II), guide service to the waterfall Rp.200,000, - / per day, guide services up to the summit of Mount Kahung 250,000, - / per day.

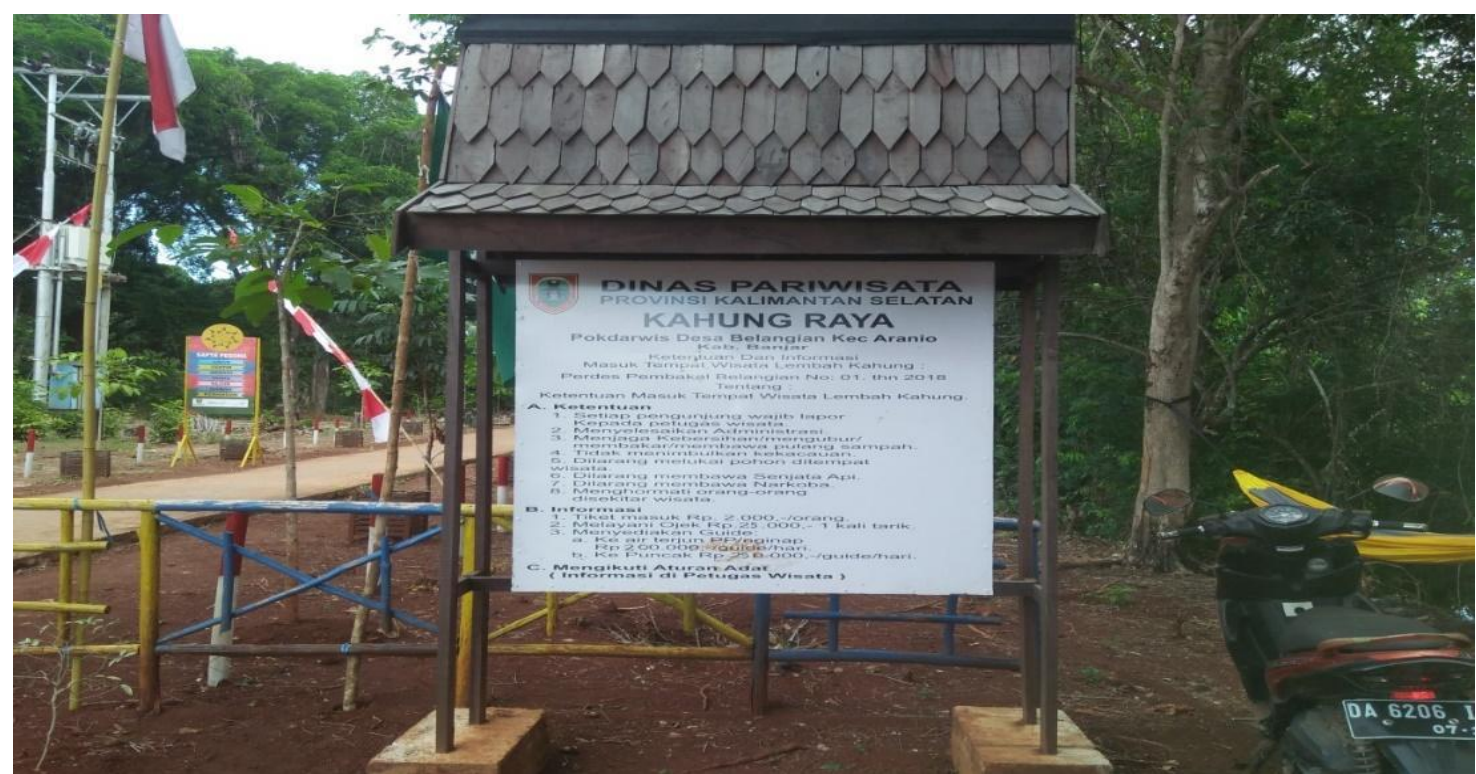

Fig-2: Announcement Board of Rules and Entrance Rates Nature Tourism Kahung Raya

With the development of Belangian Village as a Tourism Village with the Kahung Valley natural tourism as its mainstay, the village government and the village community will benefit directly or indirectly, as follows:

1. The village government gets original village income from the sale Tickets for Entrance Sign of Kahung Valley Waterfall Tourism.

2. The youth and youth of Belangian Village get additional income from motorcycle taxi services to tourist sites whose rates are following the distance/destination.

3. Youth and youth got income from services to become a travel guide/companion of Rp. 200,000 to Rp. 250,000per day.

4. Villagers get homestay services from visitors/tourists who stay at their homes.

5. Villagers get additional income from food stalls that are growing/developing.

6. Boat and klotok motorbike income from Belangian villagers are getting better due to an increase in the number of visitors.

7. Villagers get jobs and income from the construction of facilities and infrastructure conducted by the Village Government, Provincial Government, and Regency Government.

8. The expertise and skills of villagers in certain fields are getting better or increasing because of the training provided.

9. Commodities of agricultural products, plantations, livestock, and forestry (by-products) villagers the better the selling price because it is sold directly to the consumer.
10. Knowledge and insight villagers are increasing along with the flow of information that is increasingly accessed by residents.

\section{CONCLUSION}

The Community Empowerment Programs that have been implemented by the principles of community empowerment in the management of Sultan Adam's Tahura natural tourism in Belangian Village, Aranio District, Banjar Regency are as follows: 1) Program for the use of Village Fund Allocation, 2) The Riam Kanan River Basin Rehabilitation Program, 3) Forestry Program Social in the form of Forestry Partners, and 4) Tourism Village Development Program. The fourth economic impact of the Community Empowerment Program implemented in Belangian Village, the District as a whole can be concluded that it has been able to improve the welfare of Belangian Village residents because; 1) The growth and development of new business opportunities for the local community, 2) The availability of new jobs for the community, 3) Increased income of the community as a result of the increasing number of tourist visits, and 4) Opened market access to market agricultural, plantation and animal husbandry products as well as local community crafts. In the management of nature tourism in the Tahura Sultan Adam conservation area, especially those in Belangian Village, Aranio District, Banjar Regency, better coordination among stakeholders is needed so that the management of the natural tourism area can run well and not cause negative impacts. In planning the program of activities in the nature tourism area of Belangian Village, it should pay attention to the aspirations and needs of the local community so that in 
implementing the program the community feels involved and the results can be felt/enjoyed by the community.

\section{REFERENCES}

1. Syaharuddin. (2018). Persepsi Masyarakat Terhadap Program Kampung Iklim di Kota Banjarmasin [Laporan Penelitian]. Banjarmasin: LPPM ULM dan Dinas Lingkungan Hidup Kota.

2. Nyoman, I. S. (2005). Perencanaan Pembangunan Daerah Otonom dan Pemberdayaan Masyarakat. Jakarta: Citra Utama.

3. Utami, E. T. (2007). Peranan Badan Permusyawaratan Desa dalam Perencanaan Pembangunan Desa. Medan: Universitas Sumatera Utara.

4. Padmowihardjo, S. (2001). Penyelenggaraan Penyuluhan Pertanian dalam Pembangunan Sistem dan Usaha Agribisnis. Departemen Pertanian. Jakarta.

5. Gunawan, I. (2014). Metode Penelitian Kualitatif Teori dan Praktik. Jakarta: Bumi Aksara.

6. Mohammad. (2008). Metode Penelitian Kuantitatif-Kualitatif. Malang: UIN.

7. Sarman, M. (2004). Panduan Prosedur Penelitian dan Penulisan Tesis, Banjarbaru. Kalsel: Program MSAP UNLAM.
8. Nasution. (2009). Metode Research (Penelitian Ilmiah). Jakarta: Bumi Aksara.

9. Sugiyono. (2016). Memahami Penelitian Kualitatif. Bandung: Alfabeta.

10. Mardikanto, T. (2013). Pemberdayaan Masyarakat dalam Perspektif Kebijakan Publik. Bandung: Alfabeta.

11. Hitmat, H. (2004). Strategi Pemberdayaan Masyarakat, Humaniora. Jakarta.

12. Mutiani, M. (2017). IPS Dan Pendidikan Lingkungan: Urgensi Pengembangan Sikap Kesadaran Lingkungan Peserta Didik. SOSIODIDAKTIKA: Social Science Education Journal, 4(1), 45-53.

13. Arimbi, H., \& Santoso, M. A. (1993). Peran Serta Masyarakat dalam Pengelolaan Lingkungan. Jakarta: Walhi.

14. Harahab, N. (2010). Penilaian Ekonomi Ekosistem Hutan Mangrove dan Aplikasinya Dalam Perencanaan Wilayah Pesisir. Yogyakarta: Graha Ilmu.

15. Eplerwood, M. (1990). Ecotourism: Principles, Practices and Policies for Sustainability. United Nations. 